\title{
ON THE ORIGINS OF THE AFRIKAANS VERBAL HENDIADYS
}

\author{
Paul Roberge \\ Department of Germanic Languages \\ University of North Carolina, Chapel Hill
}

\section{The Problem}

Hendiadys ("one by means of two") in Afrikaans refers to a syntactic construction in which two verbal elements are connected by a conjunctive particle to express a single complex idea. The first component can be one of five verbs that denote motion (loop 'walk, go') or static modes (lê 'lie', sit 'sit', staan 'stand', and, marginally, hang 'hang'). The second component is the main verb. The connecting particle is the conjunction en 'and'.

(1) a. Hy loop en lees (Raidt 1983:179). 'He is walking along and reading'.

b. Ons lêenwag.

'We are (lying and) waiting'.

c. Hulle sit en rook op die stoep.

'They are (sitting and) smoking on the porch'.

d. Sy staan en las.

'She is (standing and) laughing.'

e. Die wasgoed hang aan die draad en droog.

'The wash is (hanging and) drying on the line.'

The subject of the hendiadys construction is normally animate. In the spoken language, however, concrete nouns frequently occur in this grammatical environment, especially when they denote items that are closely connected to animate nouns (e.g., body parts, clothes); cf. Kempen 1965:79. Abstract nouns have been attested as subjects of hendiadys constructions but this usage is exceedingly rare. ${ }^{1}$

At first glance, the hendiadys construction would appear to be nothing more than a type of compound sentence with deletion of a coreferential subject NP in the second clause. While both constructions do share common semantic properties, they differ radically in terms of their syntactic and morphological behaviour. As we see in (2), the past participle prefix ge- is attached optionally to the hendiadys trigger but never to the main verb. 
(2) a. Hy het (ge)loop en lees.

'He was walking along and reading'.

b. Ons het (gelle en wag.

'We were (lying and) waiting'.

c. Hulle het op die stoep (gelsit en rook.

'They were (sitting and) smoking on the porch'.

d. Sy het (ge)staan en lag.

'She was (standing and) laughing'.

e. Die wasgoed het aan die draad (ge)hang en droos (Kempen 1965:78).

'The wash was (hanging and) drying on the line'.

The connective particle is frequently omitted in nonstandard varieties of Afrikaans --especially in those spoken by people of colour in the Northwest (Namaqualand) and along the Orange River. ${ }^{2}$ The conjunction is also omissible in the strongly colloquial Afrikaans of Whites in the southwestern Cape Province, although De Klerk (1968:232) perceived endeletion to be in decline throughout the Afrikaans-speaking population as a whole.

(3) a. Hy sit slaap die hele tyd (De Villiers 1983:147).

'He is (sitting and) sleeping the whole time'.

b. Die hond lêt tiank daar (idem).

'The dog is (lying and) yelping there'.

c. Sy staan ril effe (Louw, Kroniek van Perdepoort, 79, cited from Ponelis 1979:241).

'She is (standing and) shivering slightly'.

In the hendiadys construction NP complements and adjuncts associated with the main verbal element can occupy a middle field position preceding the conjunctive particle.

(4) a. Piet staan 'n slas water en drink (Ponelis 1979:241).

'Pete is (standing and) drinking a glass of water'.

b. Moenie alewig oor jou lor loop en kla (idem).

'Don't be going about endlessly complaining about your lot'.

c. Hy het die heel dag vir my gestaan en pla (Bosman 1923:83).

'He was (standing and) pestering me the whole day'.

d. Onder sulke omstandighede het ek liewer by die huis gebly en na die radio (ge)sit en luister.

'Under such circumstances I preferred to remain at home sitting and listening to the radio'.

In conjoined sentences, by contrast, both verbs receive the past participle prefix ge- (data from De Villiers 1983:147): 
(5) a. Hy het op die terras gesit en die boek gelees.

'He sat on the terrace and [then] he read the book'.

a'. Hy het die boek op die terras (ge)/sit en lees.

'He sat on the terrace reading the book'.

b. Die priesters het om die stad geloop en op die basuine geblaas.

'The priests walked around the city and [then] blew on the trumpets'.

b'. Die priesters het op die basuine geloop en bloas.

'The priests walked along blowing on the trumpets'.

Furthermore, the first clause of a conjoined sentence does not attract a phrasal constituent into its middle field from the VP of its sister.

(6)
a. $\quad$ Ek het na die radio gesit en geluister.
'I sat and [then] listened to the radio'.
b. Hy lê na die golwe en kyk (Ponelis 1979:242).
'He is lying and looking at the bay'.
b'. Hy le en [hy] kyk na die golwe (idem).
'He is lying and looking at the bay'.
b". Hy le. Hy kyk na die golwe (idem).
'He lies. He looks at the bay'.
b"'. * *Hy lê na die golwe. Hy kyk (idem).
'He lies at the bay. He looks'.

There are additional empirical arguments against a bisentential analysis of the hendiadys construction. Ponelis (1979:242) points out that hendiadys does not allow the interpolation of a coreferential subject NP between the connective particle and the main verb (7a-a'). Nor does it permit the substitution of other coordinating conjunctions for en (7b-b').

(7) a. Hy lê en hy kyk na die golwe.

'He lies and he looks at the bay'.

$\mathrm{a}^{\prime}$. $\quad$ *Hy lê na die golwe en hy kyk

'He lies at the bay and he looks'.

b. Hy lê of/maar hy kyk na die golwe.

'He lies or/but he looks at the bay'.

b'. 'Hy lê na golwe of/maar kyk

'He lies at the bay or/but looks'. 
To Ponelis's arguments one could add that the relative order of verb and particle in conjoined and hendiadys structures is a mirror image of one another; namely, verb second in the former $(8 a, b)$ verb final in the latter $\left(8 a^{\prime}, b^{\prime}\right)$.

(8) a. Hy staan en gluur my so aan (De Villiers 1983:147).

'He stands and leers at me so'.

$a^{\prime}$. Hy staan my so en aangluur (idem).

'He is standing and leering at me so'.

b. Hy sit en lees koerant.

'He sits and reads the newspaper'.

b'. Hy sit en koerant lees (Kempen 1965:91).

'He sits reading the paper'.

In embedded clauses the past tense auxiliary het must stand in absolute finality. Movement of the particle directly after the past participle of the positional verb yields an infelicitous sentence $\left(9 a-a^{\prime}\right)$.

(9) a. Ek weet dat hy gister 'n glas water gestaan en drink het.

'I know that he stood and drank a glass of water yesterday.'

a'. $\quad$ *Ek weet dat hy gister 'n glas water gestaan het en drink.

The syntactic cohesion of the verbal complex is demonstrated by its resistance to such interpolation. Donaldson (1993:385) points out that when the main verb in a hendiadys sentence takes a one-word direct object, that object can be placed either to the left or to the right of the connecting particle en (10a-a'). When an object consists of more than one word, only the first order is possible (10b-b', $\left.c-c^{\prime}\right)$.

(10) a. Hy staan water en mors.

'He's standing there wasting water'.

a'. Hy staan en water mors.

b. Hy staan baie water en mors.

'He's standing there wasting a lot of water'.

b'. 'Hy staan en baie water mors.

c. Hy het baie water gestaan en mors.

'He wasted a lot of water'.

c'. *Hy het gestaan en baie water mors.

In (10a-a') the single-word direct object resembles a separable prefix (Donaldson 1993:385n.) and thus acquires the status of a Prädikatsergänzung. If that is so, then it seems likely that 
"heavier" object NPs to the right of en create a kind of structural indeterminacy between hendiadys and coordinate structures. Sentence $\left(10 b^{\prime}\right)$, for example, could entail a phantom violation of the V2 principle that would be the rule in conjoined clauses; (10c') would involve a similar trespass against nonneutralization in the past tense (infra). Unfortunately, considerations of space do not allow me to pursue this speculation further.

In Afrikaans hendiadys produces a combination aspect. Semantically, there is no lack of affinity with conjoined sentences. The pair in (11) could be judged as virtually identical: 'Piet stands drinking a glass of water'.

(11) a. Piet staan 'n glas water en drink.
b. Piet staan en drink ' $n$ glas water.

But whereas conjoined sentences such as (11b) can also be read to indicate disjunctive, - consecutive, or intermittent action, their hendiadys counterparts are restricted to simultaneous i actions. In the past tense this contrast is overtly marked, and the respective meanings are kept of strictly apart. ${ }^{3}$ Sentence (12b), for example, cannot mean 'I stood and then I shaved'.

(12) a. Ek het gewas en geskeer.

$\div \quad$ (*Ek het gewas en skeer.)

'I washed and [then] I shaved.'

b. Ek het (ge)staan en skeer.

'I stood shaving'.

c. Ek het gestaan en sukkel om die verskil te verklaar. 'I was (standing and) struggling with little success to explain the difference'.

c'. Ek het gestaan en gesukkel om die verskil te verklaar.

'I stood and [then] struggled with little success to explain the difference'.

Finally, Kempen (1965:78) observed that "le, loop en sit word net gebruik as daar werklik sprake is van $l \hat{e}$, loop of sit." Only staan, as the most frequent hendiadys auxiliary in standard Afrikaans, shows significant "bleaching", for it can express states of affairs in which no literal standing is involved. Sentence (13) would be felicitous even if the mode of action entails rolling, running, lying, or sitting.

Die hond staan en lol met die kat (Kempen 1965:78).

'The dog is teasing the cat'.

More recently, Donaldson (1993:220) has written that "although the staan and sit do not necessarily have to correspond exactly with whether the action being performed is being done in a standing or sitting position, this is most usually the case [my emphasis], and sit, staan, and le can only be used with reference to actions that can feasibly be performed in those positions." 
In general, then, it is fair to say that the lexical meanings of these semiauxiliaries have faded somewhat, but only to the extent that the focus is on the main verb in its durative aspect in hendiadys constructions vis-à-vis equal focus on both actions in conjoined structures. ${ }^{4}$

\section{Verbal Hendiadys as Netherlandicism}

Notwithstanding a wealth of previous scholarship, the etymology of the Afrikaans hendiadys remains opaque. Scholarly opinion has vacillated between Netherlandicism, creolism, or some combination of both.

The received opinion in South Africa has long been that the Afrikaans pattern is a legacy (erfgoed) of Early Modem Dutch. Proponents of a Netherlandic origin have drawn attention to the fact that a combination of verbs in a hendiadys with liggen, staan, and zitten originated in Middle Dutch (14) and has become rather common by the seventeenth century $(15-16)^{5}$

(14) Middle Dutch:

a. Hij stont ende dachte (Stoett 1923: par. 13)

'He stood and thought', i.e., 'he stood thinking'

b. Noe lach ende sliep (idem)

'Noah lay sleeping'

c. hi sat ende at (idem)

'he sat eating'

(15) Early Modem Dutch:

a. hoe legddy so en preutelt (Bredero, Rodderick ende Alphonsus, Knuttel ed., p. 68)

'how he is prattling so'

b. dat jij hier lecht en tabackt (Bredero, Griane, p. 105)

'that you lie here and smoke tobacco'

c. ' $k$ hadd loopen hoore preke (Trijntje Cornelis, vs. 1204)

'I had gone to hear [the] preaching'

d. Hoe brill sel onse Claes staan kvken (Trijntje Cornelis, vs. 367)

'How embarrassed will our Klaas be (standing and) looking'

e. $\quad N u$ dat de Hel-heer lang vewondert had staan staren (Bredero, Angeniet, vs. 1495)

'Now that Satan had been (standing and) staring confused for a long time'

Kempen (1965) conducted a very thorough investigation of hendiadyslike constructions in metropolitan Dutch from the middle ages through the seventeenth century, comparing these structures with what we find in Afrikaans. He sought in particular to establish Netherlandic 
cognates for properties that had previously been thought to be creolisms, such as the absence of en in colloquial and nonstandard Afrikaans (staan praat, le staan, etc.). In Dutch this particle is normally omitted only when an auxiliary verb is present (15c-e). Yet, Kempen (1965:87-88) turned up instances in which liggen, stoan, and loopen can occur without a connective particle and outside the environment of a tensed auxiliary verb.
a. ... en gedurigh ... leggen luisteren ... (Asselijn, Echtscheiding van Jan Kloasz) 'and continously ... lie listening'
b. Sy liep by heur smockelmoèren rinkelroyen (G.C. van Santen, Lichse Wigger, 1627)
'she went to make merry with her rakes'
c. En zoo ... staan labbekakken aan de deur (Asselijn, Ecthscheiding van Jan Klaasz) 'and so stands gossiping at the door'

Kempen further pointed out that an adjunct, an NP complement, or the main verb can occasionally occupy a middle-field position following the positional verb.
(17) a. ge leghme soo en vatt (Trijntje Cornelis, 662)
'you are gripping me in this way'
(= Afr. jy staan en vang my so, according to Kempen 1965:89)
b. Een waterlantsche Trijn sat eens qivun en schilde (Jacob Cats, cf. Woordenboek der Nederlandse Taal (WNT) III/e, col. 4109)
'A Waterland maid once sat peeling onions'
c. en ... doen het waeckent haentjen sot en droomde op sijn nest (D.A. Opmeer, Trijn Ratels, 1660)
'and then the rooster, awake, sat and thought in his bed'

The probative value of one of Kempen's supporting examples (17c) is of course debatable, for it is not entirely certain that its main verb (en droomde) has been moved. And it is important to bear in mind that the putative Netherlandic antecedents are in the main to be analyzed as conjoined structures (cf. Weijnen 1968:par 87). Nevertheless, the parallelism between (17a-b) and the Afrikaans sentences in (4) is striking.

Since the seventeenth century, however, it has been the complementizer te that has been used between the positional verb and the main verb (the latter in the infinitive form).

(18) a. Hij staat te kijken.

'He stands [there] and looks'.

b. Wij liggen te wachten.

'We are lying and waiting'.

c. Zit niet rezeuren.

'Don't sit [there] and worry'. 
d. Hij loopt te lezen.

Like its predecessor en(de), the connecting particle te is omitted when the finite verb is an auxiliary (Donaldson 1984:154-55, 170).

a. Hij zit een boek te lezen.

a' Hij heeft de hele dag een boek zitten lezen.

'He has been (sitting) reading a book all day'.

b. Zij stond naar een koe te kijken.

'She stood looking at a cow'.

b' Ze kan urenlang naar koeien staan kijken.

'She can stand looking at cows for hours'.

The Modern Dutch equivalent does not date back further than the seventeenth century and did not gain significant ground until perhaps even the eighteenth century (Brachin 1985:124). However, the Afrikaans pattern is not a continuation of the Dutch infinitival hendiadys. According to the Netherlandicist position, it was the older structure with en(de) that persisted in the metropolitan volkstaal and was exported to the Cape of Good Hope, whence Afrikaans Hy staan en kyk beside Modern Dutch Hij staat te kijken. ${ }^{6}$

Kempen has made a very compelling case for a monogenetic Netherlandic origin of the Afrikaans hendiadys construction. Many accept his conclusion as definitive, if not inescapable: "Gesien die Nederlandse ouderdom van die verbale hendiadis en die verskeidenheid in sy waardes en vorme, lyk dit merkwaardig dat Afrikaans, wat geografies 300 jaar gelede volkome geskeie geraak het van Nederland, so oorwegend 'Nederlands' gebly het. Daar is geen grond voor om of die woord of die begrip 'Kreolisering' in dié verband te gebruik nie ... of ons moet dit van 17de-eeuse volksnederlands in Nederland self ook doen, en dan kan 'gekreoliseerd' in dié verband alleen 'volks' gaan beteken en dus misleidend en oorbodig word" (1965:96).

When viewed dispassionately, however, Kempen's etymology leaves several issues unresolved. I should think this a topic that would invite some consideration of the formation of a syntactic unit in which the past participle marker ge- stands (optionally) before the positional verb, the main verb remains in the infinitive, and the connective particle intervenes (gestaan en sukkel). To the best of my knowledge, this structure has no precedent in Dutch. Postulation of a vernacular hendiadys involving nonfinite main verbs (as illustrated by hij lag en slapen 'he lay sleeping' in West Flemish) and subsequent "contamination" in Cape Dutch (whence Afrikaans hy het gele en slaap beside Early Modern Dutch hij lag en(de) sliep, Modern Dutch hij lag te slapen) is hardly convincing (cf. Kempen 1965:93). ${ }^{7}$ Another problem is that the Afrikaans hendiadys with loop finds no direct metropolitan cognate in either medieval or Early 
Modern Dutch and must therefore be treated as an autochthonous innovation. ${ }^{8}$ In principle this is not an unreasonable assertion, but unless one were to adduce much more empirical support from our Cape Dutch source material, it is merely an assumption. But even allowing for Dutch loopen having been left out of the loop, so to speak, one finds it difficult to accept the idea that liggen -.- arguably the most desemanticized of the positional verbs in Early Modern Dutch -has become resemanticized in the Afrikaans hendiadys. ${ }^{9}$ Recall that standard Afrikaans does not allow the use of $l \hat{e}$ in hendiadys if the subject is not actually lying, or the action cannot be performed from a prone position. Sentence (20), with an inanimate subject, is infelicitous in standard Afrikaans (though entirely possible in Orange River Afrikaans).

(20) Standard Afrikaans:

a. $\quad$ Die rivier le (en) loop (Kempen 1965:96).

'The river is flowing'.

Early Modern Dutch:

b. Men leghten loopt dat's duytsche spraeck.

Welck is het vreemdst,

' $t$ Woord of de saeck?

Men ken niet sotter seggen;

Wy loopen en wy leggen

(Huygens, "Quaed Goed Duytsch", Sneldichten)

'One "lies and runs" [i.e., is running]

that's the Dutch vernacular.

Which is stranger, the word or the idea?

One cannot more foolishly say,

We run and we lie'.

c. maer dat jy noch wilt leggen en loopen (Bredero, Griane, p. 185)

'but that you still want to lie and run'

Finally, there is the matter of en linking positional and main verbs following a finite modal auxiliary, of which Kempen provides but a single potential example (20c). However, this datum is not analyzed nor is the broader issue even apprehended. One cannot take a Netherlandic origin for granted on the basis of a single, isolated example.

I suppose my main resistance to the Netherlandicist position has to do with the fact that the hallmarks of the Afrikaans verbal hendiadys are conspicuously absent in our Cape Dutch sources from the seventeenth, eighteenth, and nineteenth centuries. Raidt (1983:181) lists thirteen putative examples of the Afrikaans hendiadys from the source material. Of these, eleven fail to show any of the features that distinguish the Afrikaans hendiadys from its putative Netherlandic antecedents: ${ }^{10}$ 
(i) Deflected or nonfinite main verbs following the positional verbs staan, zitten, and liggen. In the Cape Dutch sentences in (21) both verbs are finite:

(21) a. terwijl den ersten Comp [arant] lag en sliep in 't groote huijs van gem- hofsteede (Crimineele Justitien (CJ) 1029, $\mathrm{nr} .214,1715$ )

'while the first partner lay sleeping in the big house of the aforementioned farm'

b. of hij den drosser Jan dirks Evers niet op seekeren Nagt, terwijl den selven lijen sliep verscheijden gaeten met een schop in 't Hooft geslaegen heeft. (CJ 333, p. 9, 1729)

'whether on a certain night he didn't beat the deserter Jan Dirx Evers Igiving him] several holes in the head with a spade, while the aforementioned lay and slept'

Only (22a-b) appear to be instances of the Afrikaans hendiadys, and even these are not far removed from their conjoined counterparts in (21).

(22) a. en jij maar altijt staat en vloek en schellit mijn (Kaapse Taalargief (KT) 206, 1810) 'and he just stands there the whole time cursing and verbally abusing me'

b. op de dag als ik sat in schreyf kreeg ik de teydeng van de moort van meijn ge eerde ouwe heer landrots (KT 223, 1812)

'on the day that I sat writing I received the news of the murder of my honored old [friend] lord magistrate'

Van Oordt $(1952: 79,90)$ regarded these forms as equivalent to the Dutch infinitival hendiadys (staat te vloeken, sat te schreyven, respectively), and semantically this seems beyond question. Then again, vloek and schelt in (22a) are endingless but still finite third-person singular forms. The writer, Foucee, attempts to maintain a formal distinction between infinitive and finite verbs, although he is admittedly not altogether successful in this effort. If in (22b) schreyf is a deflected infinitive, then we would have here an unambiguous hendiadys that would lend slight support to Kempen's version of the Netherlandicist position. If, on the other hand, this form is merely the first-person singular of the present tense, it is of negligible significance. The temporal dissonance in the verb complex does not contradict this possibility in the least, for such stylistic refinements mattered little to poorly educated field cornets. So far as I have been able to determine, the next probable case of Afrikaans hendiadys does not occur until 1837 in the diary of the Voortrekker leader Louis Trigardt (infra).

(ii) The positional verb takes the form of the past participle in perfective tenses. There are no examples of this feature in our Cape Dutch source material. Raidt (1983:181) considers (23) an instance of hendiadys:

david en baco bij de combuijs met den anderen gestaan en dispuut gehad hadden (CJ 390, p. 1066, 1766)

'David and Baco had been standing by the kitchen with the others and had a dispute' 
In this example, however, the addition of the past participle prefix to both verbs makes it all but certain that (23) is comprised of two conjoined clauses and is not a hendiadys.

(iii) The interpolation of the conjunctive particle between positional and main verbs in the environment following a finite future, modal, or perfect auxiliary. The sentences cited by Raidt in (24) contain double infinitives with no connecting particle, as we should expect. As such, these sentences, too, continue the metropolitan tradition.

(24) a. Ik hebbe leggen slaapen (CJ 345, p. 189 and opp. p. 190, 1740) 'I was lying (lay) sleeping'
b. aan tafel heeft sitten eeten en drinken (CJ 345, p. 218, 1740) 'at the table was sitting (sat) eating and drinking'
c. $\quad \ldots$ in 't pad leggen slaapen (1744) 11 '... lie sleeping in the road'

d. Gij moet mij niet kullen, want ik zal loopen kijken of 't wel waar is (CJ 379, opp. p. 30, 1762)

'You must not talk rot to me, for I shall go see whether it is indeed true'

e. [dat hij] in de combuijs had leggen slaapen (CJ 391, opp. p. 99, 1766) '[that he] had been lying sleeping in the kitchen'

f. had deselve op de herhaalde bedrijging haarer lijheer sig naar de kamer begeeven en teegens de post der kamer deur staan leunen (CJ 387, opp. p. 131, 1766)

'the aforementioned had proceeded to the room upon the repeated threat of her master and stood leaning against the post of the room'

g. dan sou heij wel ander staande keijke (KT 12, 1770)

'then he would otherwise stand looking'

Of this group, only (24g) could possibly be an instance of Afrikaans hendiadys. To sustain this view, one would have to show that the paragogic vowel in staane is to be resolved as an enclitic (staan $+e n)$. This is not unthinkable from the standpoint of Modern spoken Afrikaans (cf. Heiberg 1963:141n.), in which en can attach itself to staan as a clitic. However, hypercorrect reinflection of the monosyllabic infinitives staan, doen, and zien is not unusual in our Cape Dutch materials, e.g., dat hij die slaaven ... heeft siene staanen met haarle voeten op die grond 'he has seen the slaves standing with their feet on the ground' (CJ 399, p. 709, $1770)$. I think this the more plausible explanation of staane in $(24 \mathrm{~g})$, especially in view of a reinflected past participle (gedaane het 'has done') in the same letter (KT 12, 1770).

(iv) Middle-field placement of NP complements, adjuncts, and main verbs. No attestations are to be found in our source material before 1800 , save for the imperatives in $(25 a, d)$, infra. 
(v) Loop as a hendiadys trigger for concurrent actions (viz. walking along while doing something). This is all but unknown in our Cape Dutch materials. The verb loopen indicates movement away from a deictic center (much like gaan) and occurs without a connective particle. To supplement Raidt's example (24d), I have culled the following:

(25) a. Jan Dirx daar op zeijde loop begraaf die hottentot (CJ $311, \mathrm{nr} .434,1707$ )

'Jan Dirx said thereupon: go bury that Hottentot'

b. en denselven dus al duijkende, naar den Relatant liep soeken, onder 't seggen: waar is hij die moerneuker (CJ 408, p. 119, 1772)

'and sheltering the aforementioned [he] went looking for the witness saying: Where is he, that motherfucker'

c. gij bent beschonken, loopt slaapen (CJ 407, p. 317, 1774 [actually 2 tokens on p. 317 and two more on pp. 393, 394 --- PTR]) 'you are drunk; go sleep'

d. hier is water loop laaf hem (Duminy diary, 1797 [Franken, ed., 1938:87]) 'here is water; go revive him'

The placement of the direct object after the main verb in the imperatives (25a, d) is not without interest, to be sure. But aside from this, the usage of loopen so far confronts us with no significant innovations as concerns the hendiadys itself.

(vi) Desemanticization of positional verbs (especially liggen), which we encounter periodically in metropolitan Early Modem Dutch. This phenomenon is nowhere evident in our Cape Dutch texts (although it must have been present in spoken language). So far as one can tell, all of the positional verbs attested in our Cape Dutch archival materials have more or less retained their lexical meanings.

At the same time, Cape Dutch does preserve the infinitival hendiadys that was gaining currency in the metropole during the eighteenth century.

dat de baas Thuijnier met eenig ander Volk omtrent de Thuijn Deur zaten te drinken (CJ 319, p. 472, 1715)

'that the head gardener with some other people sat drinking around the garden gate'

Louis Trigardt uses the infinitival hendiadys nine times in his diary, e.g.

Stond zij allen ce kijken (Trigardt diary, 1836)

'They all stood there looking'

By contrast, hendiadys with en as the connective particle in (28) is a hapax legomenon (Smuts 1969:39). 
de morgen lii hij dig bij de wagen en slaap (Trigardt diary, 1837) 'in the morning he lies sleeping close to the wagon'

Smuts (loc.cit.) attributes the former usage to the influence of Dutch written norms but this seems hardly likely, especially in a private document (cf. Roberge 1994). I make so bold as to suggest that the younger infinitival hendiadys was the unmarked competitive alternate in the spoken Cape Dutch of Europeans. It is present in the writings of the nineteenth-century journalist Louis Henri Meurant (1812-1893), who sought specifically to exploit the vernacular o style of the colonists. In fact the complementizer $t e$ has coexisted as a connecting particle even $\stackrel{\sim}{N}$ into the present century:

Onder slap ooglede lê Attie net nog 'n oomblik te kyk (Louw, Kroniek van Perdepoort, 77; cited from Ponelis 1979:241)

'Under heavy eyelids Attie was (lying and) looking for just another moment'

Since the 1920's, however, this usage has gradually disappeared from written Afrikaans and survives only vestigially, if at all, in spoken Afrikaans in specific regions of the northwestern Cape Province. 12

To recapitulate: Concerning the etymology of the Afrikaans verbal hendiadys, the Netherlandicist position leaves unanswered five vitally important questions: (1) why attestations of the Afrikaans hendiadys are so sparse throughout the entire Dutch colonial period (16521795); (2) the emergence of the syntactic unit implementing the perfect (Afrikaans past) tense; namely with optional affixation of the past participle marker ge- to the positional verb and interpolation of the conjunction en; (3) extension of the connective particle into hendiadys environments following finite modal and future auxiliary verbs; (4) the emergence of loop as a hendiadys trigger; (5) the striking absence of strongly desemanticized hendiadys triggers in our Cape Dutch corpora. We shall certainly have to stipulate that movement of phrasal constituents into the middle field following a positional verb was at least weakly present in seventeenthcentury Dutch; and further that liggen had undergone significant desemanticization already in the metropole. These facts are necessary but not sufficient to sustain the Netherlandicist position, which explains the obvious and leaves. what is not obvious to the workings of some invisible hand.

Particularly awkward for the Netherlandicist position is the curious relative chronology for what was supposedly an ordinary feature in the Dutch volkstaal of the seventeenth century. Bouman (1926:7) considered the Afrikaans hendiadys "[een] van de voomaamste afwijkingen van Nederlands op syntakties gebied." Yet, unlike other salient Africanderisms, the hendiadys construction as we know it in Modem Afrikaans seems to have passed beneath the notice of the early lexicographers, grammarians, and dilettante observers. This fact alone suggests that the Afrikaans verbal hendiadys must be somewhat younger than the Netherlandicist position would 
have us believe, and that its antecedents may lie elsewhere, namely, in basilectal forms of Afrikaans.

\section{Verbal Hendiadys as Creolism}

Hesseling (1899:129-30, 21923:105) and, following his lead, Du Toit (1905:94-97) were the first linguists to take notice of how positional verbs could indicate aspect in Afrikaans. What they described, however, was not the hendiadys construction we know today in Standard Afrikaans but rather aspectual functions of $l e$, staan, loop, and aanhou 'continue' in nonstandard varieties of Afrikaans. While noting hendiadys constructions in Dutch and "beskaafde" (lege Euro-) Afrikaans, Bosman (1923:83) observed that "creole" (lege "Coloured") Afrikaans goes much further: "Ook in Hollands het ons uitdrukkinge soos staan te zaniken ['be (standing and) pestering'], liggen te zeuren ['be (lying and) worrying'] waar staan en liggen kan opgevat word as duratiewe hulpwerkwoorde, maar Kreools-Afrikaans gaan hierin baie verder. Ook in beskaafde Afrikaans kom sulke uitdrukkinge af en toe voor den dag: hy het die heel dag vir my gestaan en pla $[=(4 c)]$." Clearly, Bosman considered hendiadys a creolism, a hallmark of the basilect, and most tellingly a marginal feature ("af en toe") of Euro-Afrikaans. Even Kempen (1965:82) had to concede that in Euro-Afrikaans hendiadys may have been far less common in Bosman's day than four decades later, by which time it had become "algemeen en dikwels."

The basilectal equivalent of the hendiadys construction omits the connective particle altogether and shows verb-second placement of main verbs in root clauses, which suggests that the positional verbs are proclitic. As a preverbal aspectual marker, sit has not distanced itself drastically from its lexical meaning. In (30) the action is literally or plausibly performed when one is seated.

(30) a. Nou kry elke skool sy plekkietjie war hulle moet sit. Nou sit sing hulle virie heeldag. (Van Rensburg, ed., 1984:II.133)

'Now every school gets its little place where they must sit. Now they sit singing the whole day'.

b. Jy maak jôu ôghe toe solat jy kan die Here se woord mooi sit luister (Van Rensburg, ed., 1984:II.272)

'You close your eyes so that you (sit and) listen to the word of the Lord'

As an aspectual marker, $l \hat{e}$ indicates that an action occurs over an extended period of time. As such, $l \hat{e}$ has undergone significant desemanticization, and scholars have interpreted it variously as an exponent of "progressive", "continuative", "iterative", or "durative" aspect. ${ }^{13}$

(31) a. Ek lê praat fan die ding (Du Toit 1905:95).

'I speak about this thing continuously'. 

b. Wagoet baas le slaan fer mij? (idem)
'Why is the master beating me?'
c. Waar is Jan? Hij le kom nog (Rademeyer 1938:78)
'Where is Jan? He's coming (but very deliberately)'
d. Hy lê loop met die pad saam (idem).
'He is walking along the road'.
e. Wat lê lôp Piet dan weer số langsamag? (idem)
'Why is Piet walking along so slowly again?'

In many cases the meaning of $l \hat{k}$ has faded to the point of pleonasm (cf. Rademeyer 1938:78):
(32) a. Hy lê weet neeks van die saak af nie (Rademeyer 1938:78).
'He doesn't know anything about the matter at all'.
b. $\quad$ Die rivier lêे loop (= [20a]; Kempen 1965:96).
'The river is flowing'.

With the auxiliary het, le may have denoted perfective (completed) action, although additional research is indicated.

(33) a. Die fijand het mijn been le breekskiet (Du Toit 1905:95).

'The enemy has shot (off) my leg'.

b. Die noi het fer mij melk lê gé (idem).

'The mistress has given me milk'.

As we have already seen, liggen + en (de) had desemanticized to a considerable degree in Early Modern Dutch, and Kempen (1965) was surely correct in supposing this must have been the case in extraterritorial vernaculars as well. Seventeenth-century writers frequently confused liggen with leggen much like contemporary English speakers neutralize lie/lay; cf. Weijnen 1968: para. 43. Both verbs eventually fall together as $l \hat{e}$ in Afrikaans. Eighteenth-century Virgin Islands Dutch Creole had le (<leggen) as a progressive marker, which eventually gave way to lo (<loopen); cf. Hesseling 1905:104-6.

(34) Virgin Islands Dutch Creole:

a. Da sender a le visch.

'Were they fishing?'

b. Em le slaap.

'He/she is sleeping'.

c. Ons le werk.

'We are working'. 
As a preverbal aspectual marker, staan is similar to le in meaning, although it often bestows a nuance of habit, intentionality, even premeditation or defiance to an activity (vis-àvis an activity that is in the nature of things or not established as a regular pattern). Not surprisingly, staan can convey a decidedly negative evaluation of habitual or deliberate action on the part of the speaker.

(35) a. Hij stan melk die koeie elke dag (Du Toit 1905:95).

'He milks the cows every day'.

b. Jij stan speul as jij moet werk (idem). 'You are accustomed to playing when you must be working'.

c. Jij het mijn twak stan oprook (idem, p. 96).

'You have smoked all my tobacco up'.

d. Dan staan loop hy jimmers tot daar duskant die rooi rankie (Rademeyer 1938:86).

'Then he would actually walk as far as this side of the little hill [randtiie]'.

e. Hy't klaa gekalf ... ons stan melk hom ... (Van Rensburg, ed., 1984:II. 151) 'She has already calved; we are milking her'

In the future staan expresses an action that, once having commenced, is likely to continue.

(36) a. Jij sal stan steel tot jij gevang word (Du Toit 1905:96).

'You will continue to steal until you are caught'.

b. jij sal nog so stan loop bij die kerkhof voorbij tot die spook fer jou fang (idem). 'You will walk by the cemetery until the ghost gets you'.

The older literature reports that the verbs staan and lê could be used together (staan-lê, lêstaan).

(37) a. Jy le stan skent Grikwa se kind by die korakter (Ons Klyntji II, p. 89, ca. 1896, cited from Hesseling 1899:129)

'You are defaming the Griqua's character'

b. $\quad$ Die honde staan-lề blaf (Bosman 1923:83).

'The dogs are barking'.

Orange River Afrikaans shows two usages of preverbal loop. The first, of course, is the familiar motion verb common to all varieties of Afrikaans expressing movement away from a deictic center. In its most literal meaning, loop typically occurs in utterances that can be taken as identical to ones with gaan 'go'; and it is especially common in imperatives.

a. da moe'jy loop kjyk (Van Rensburg, ed., 1987:81)

(dan moet jy gaan kyk)

'then you must go look' 
b. daar loop vat (gaan vat) hulle hul'se ding (idem, p. 79)

'there they go take their thing'

c. loop huur ons ' $n$ mouter (idem, p. 84)

(gaan huur ons ' $n$ motor)

'go hire us a car'

d. nou loop hulle nou skool toe (Van Rensburg, ed., 1984, II:137)

'now they go to school'

$\hat{\varphi}$ Predictably, the syntax of loop parallels that of another motion verb expressing movement toward a deictic center, viz. kom 'come' (cf. Du Plessis 1984:141-47).

ek moet vir [die kjent] sê moenie. war hy verkeerd gan, en vandag is dit mos nou so dat jy vir die kjent sê moenie, dan loop sê die kjent vir sy ouerse: hyt darso mer my geraas en jy sit nog so dan kom iemant, hy kom slaan jou oè vir jou toe, oor die wat jy mer sy kjent geraas het ... (Van Rensburg, ed., 1984:II:139)

'I have to tell the child "don't" when he does wrong. And today it is the case that when you tell the child "don't," he goes and says to his parents: "That guy over there hassled me." And you are sitting there, and then somebody comes and puts your lights out for you for giving his kid a hard time'

Orange River Afrikaans has, in addition to the motion verb loop, a second loop that has a semantic value that is unrelated to spatial motion. It has been asserted that loop in Orange River Afrikaans can mark the immediate future (Du Toit 1905:96), but it does not actually implement a tense. Rather, it expresses inchoative Aktionsart, referring to the beginning of an action or state. More specifically, loop, as a semiauxiliary, indicates a transition from the moment of speaking or from prior events to the initial phase of some other event. Because the transition can itself take place entirely in the future, the future auxiliary sal is appropriate.

(40) a. Jij loop huil vandag! (Du Toit 1905:96)

'You'll be crying today'.

b. $\quad$ Ek loop krij fer jou (idem).

'I'll catch you'.

c. Welaf mense wat banje goete gehet het: skap, bees, pert, vark en wat wat soos 'n baas gewees het op die plek, moes toe loop wérk om te lewe (Van Rensburg, ed., 1984:II.131)

'Well-to-do people who had many things --- sheep, cattle, horse, pig, and so on, like a white man on the farm -.- had go to work [i.e., take up employment, start working] then in order to live'

d. hier sit hy -- Hy keik, hy loop staan hy kjeik jou nog om hy sal stadag loop tôt da by daarie pomp. Jy sê hartkloop [sic] mar hy sallie hartkloop nie. (Van Rensburg, ed., 1984:1I.18).

'here he sits --- he looks, he gets up, he looks at you still; he'll walk slowly toward the pump over there. You say "run", but he won't run'. 
e. IIn response to a question of whether there are only Griqua children at a particular school:] Ha is hieriese meneer wat weer oorie draad spreng en anner soort nasies lop kry. (Van Rensburg, ed., 1984:11.152)

'Here is this [school], sir, that again jumps over the wire and winds up with other kinds of people'.

f. hierie mense loop gee solke snaakse name (Van Rensburg, ed., 1987:81) 'these people just up and give such funny names'

g. As dit net loop reent, dan sal die skape loop fet worre (Du Toit 1905:96). 'If it would just rain, then the sheep will [begin to] thrive'.

h. $\quad$ sal menier dan nie weer ló,p slagp'ie (Van Rensburg, ed., 1987:81) 'will you not go sleep again, sir?'

To be sure, gaan can also indicate "external phasing" in standard Afrikaans (as it does in Dutch) and could substitute for loop in most such cases. ${ }^{15}$ However, Orange River Afrikaans goes somewhat further insofar as loop can co-occur after gaan. Whereas gaan conveys the external phasing in this environment, the scope of loop narrows such that it focuses specifically on the beginning stage of the event itself.

(41) a. [die kjenerse] ... uitgan en daar ok dai sportse en goete loop doen (Van Rensburg, ed., 1984:II.120)

'the children ... go out and also do those sports and things there'

b. hulle was drie(e) gawees wat gegan het om te loop leer vir leraarts (Van Rensburg, ed., 1984:II.79)

'there were three of them who went to begin studying [to become] teachers'

c. ... En in darie dage was dit mosnie so gawesie. Is jy verkeerd gedoen het en jy gan nog en loop sê vir jou ma: of jou pa: "Daarie oom het my geslaan." "Wat het, jy het seker verkeerd ..." (Van Rensburg, ed., 1984:II.139)

.... And in those days it was just not so. If you had done wrong and you went and up and told your ma or your pa "That man gave me a hiding," [they would say] "What did you do? -.- surely you did something wrong"'

d. $\quad$ hy gan net lôp fees, dan kom lè hy vôrie deur (Van Rensburg, ed., 1984:II.273) 'he [a dog] goes just to have fun [before he is shot], then he comes [back] and lies by the door'

e. da gaat ô:s die gronde loep verloor (Van Rensburg, ed., 1987:79)

'we are going to lose (start losing) our land'

f. die lop gan jy mos dê:r (idem, p. 83)

(jy gaan daardeur)

'you just go through it'

The two types of loop that we find in Afrikaans today constitute what Spears (1982) has called "camouflaged forms." In this case, however, the camouflage is only partial, for there is a smoothly intergrading series of meanings between semantic poles (cf. Du Plessis 1984:132- 
41) rather than two homophonous but entirely unrelated usages. By the middle of the eighteenth century, this basilectal usage of loopen has apparently infiltrated Euro-Cape Dutch:

dat meergem. Bernardus de billion ... sijn werk heeft neder gelegt en gaen Loopen speelen is (CJ 2978, p. 305, 1745)

'that [the] oft-mentioned Bernardus de Biljon ... has laid down his work and is gone [and has begun] to play'

I make so bold as to suggest that loop expressed momentary action in an earlier Cape Dutch creole. This type of action by its very nature could never coincide in time with its verbal expression, whence a continuum of meanings ranging from spatial motion to inchoation to immediate future. Not only is loop compatible with intrinsically inchoative and punctual verbs (word 'become', afsterf 'die'), but it is attested periodically with adjectives --- often with perfective meaning.

(43) a. wanner hy [die stok] loop droog is (Van Rensburg, ed., 1987:82)

'when it [the vine] has become dry'

b. wanner hy [die bessies] nau loop rop word (idem)

'when [the berries] have become dry'

c. toe die oukjèrel loop oúd word (idem, p. 83)

(toe hy oud geword het)

'when the old fellow became old'

d. toe't die oukêrel daar lop afgesterf (idem)

'then the old fellow there (up and) died'

e. $\quad$ hy lôp saf bas (Van Rensburg, ed., 1984:11.245) ${ }^{16}$

'it has become soft, master'

It has been pointed out often enough that in "basilectal" Afrikaans the positional verbs function more like verbal prefixes, which of course is one of the most striking features of creole languages. ${ }^{17}$ Following a suggestion of Bouman (1926:40) in regard to basilectal staanle, Valkhoff (1972:23-24) argued that this combination of verbs in basilectal Afrikaans represents a transfer of $\mathrm{L} 1$ syntax from Khoikhoi languages. ${ }^{18}$ More recently, Den Besten (1988:32-40) has come out against substratum influence and has emphasized speaker reliance on universal strategies resulting in a " $V+V$-Verschmelzung". In this matter $I$ believe he is on the right track. The mechanism appears to have been a pragmatic serialization of Dutch lexical verbs to indicate directionality (i.e., motion toward or away from) or stasis. At the outset, these "deictic" verbs were semantically transparent to the extent that they preserved their superstrate lexical meanings. In creolized varieties of Afrikaans they were reduced to grammatical formatives such that they encoded a fundamental category of the verb: punctual (momentary, inchoative) versus nonpunctual (continuous, durative) action. 
Whether such concatenations ultimately gave rise to the hendiadys, as Valkhoff thought (loc. cit.), is another matter entirely. It does not follow from the facts presented here that Orange River Afrikaans necessarily preserves the parent form, even if Netherlandic cognates for every property are not in evidence. Bouman (1926:25) saw no connection at all between the acrolectal hendiadys and basilectal structures like le praat van die ding 'be speaking about the thing'. Rademeyer (1938:73) suggested that basilectal forms without en (e.g., die vrou staan was 'the woman is washing', sy le slaap 'she is sleeping', etc.) could be analogical creations on the model of hy loop eet = hy gaan eet 'he is going to eat', which, as he correctly pointed out, is completely different from hy loop en eet 'he walks along eating'. The possibility of secondary autochthonous innovation should sound a note of caution to anyone who might at this point champion a creolist solution to the question of the origin of the Afrikaans hendiadys. 19

\section{Verbal Hendiadys as a Hybrid Structure}

If we now consider how basilectal Afrikaans can illuminate the problematic aspects of this etymology, we encounter difficulties of a different sort. Data on the creolized Dutch that we impute to the African substratum is scanty in the extreme throughout the formative periods. Neither the fragmentary utterances in "Hottentot Dutch" that have come down to us from the Dutch colonial era nor the comic sketches of the nineteenth century (most notably those of Boniface) show any form of the hendiadys. Asice from these minimal texts, the presumed creole ancestor is recoverable only on the basis of features attested in its modern descendants, among which Orange River Afrikaans figures prominently. In the case of a language without sufficient diachronic attestation, two assumptions become crucial --- one general and methodological, the other substantive and case-specific. The first assumption finds ample precedent in traditional dialectology and is presumably uncontroversial; namely, the speech of nonmobile, rural, less-well-educated, and especially older speakers is assumed to be conservative, least affected by the normative influence of the prestige standard (ceteris paribus), and more faithfully reflects older stages of language. Second, Van Rensburg has asserted that "it does not seem as if the [Orange River Afrikaans] of the present day descendants of the earlier speakers differs remarkably from the earlier recorded forms (e.g. Rademeyer 1938)" (1989:137). While this is doubtless true in general terms, I shall assume nonetheless that Orange River Afrikaans has been in a gradual but inexorable state of decreolization over the course of the past two centuries.

If we attempt now to sketch out the development of the acrolectal hendiadys, it would appear that there was a rapprochement between Netherlandic constructions with erstwhile finite verbs separated by en $(14-15,22)$ and the basilectal serialization summarized in (44). Positional verbs that came to be used as preverbal elements in basilectal Cape Dutch are 
reductions of what were strictly lexical verbs in acrolectal Cape Dutch. Their preverbal position in the basilect is inconsistent with the verb-second principle of continental West Germanic languages.



¿aNevertheless, these structures, I submit, were eminently mergeable after verb deflexion had frun its course in Cape Dutch. Acrolectal speakers could easily "Netherlandicize" the basilectal Oुpattern (44) by moving the main verb to clause-final position or by introducing the conjunctive particle en in the present tense --- or both. This adaptation had the effect of breaking up the serial verb cluster, thereby resolving an apparent verb-second violation and creating a more Dutchlike structure. The Netherlandic erfgoed, therefore, provided a kind of "hook" for a क्.
Accommodation was demonstrably mutual. European speakers of Cape Dutch did not fully resist basilectal forms, the result of which is the colloquial variants in (3). During the N930s Rademeyer found that "die staan en praat-konstruksie skyn die kleurling vreemd te क्षvees: die en word verswyg" (1938:73). Today in Orange River Afrikaans there is competition from the full hendiadys under the influence of the standard language, although the latter is Gather less frequent (cf. Du Plessis 1984:132-33).

$\stackrel{\Phi}{\overline{0}} 45) \quad$ a. 'ie man moenie loop staan in sê dit moet ...

(= die man moenie sề dit moet ...) (Van Rensburg, ed., 1987:80)

'the man must not (stand there and) say it must ...

b. Dis waarvoor ons ok mar meeste vannie tyt ok mar sit 'n bit en smeek (Van Rensburg, ed., 1984:II.92)

'That's why most of the time we also just sit and pray a bit [that the spring rains will come]'

c. Staan daar ront en sing en sing (idem, p. 133)

'Stand around singing and singing'

d. pa nou hier sit en gesels sos nou ek en meneer nou (idem, p. 138) 'pa now sits talking here just like you and I, sir, [are doing] now'

e. as die vleis slaa en kook (idem., p. 240) 'while the meat cooks' 
f. Want somtyds as djy innie nág ôk lêe en slap (idem, p. 70)

'For sometimes when you are sleeping in the night'

For its part, Orange River Afrikaans seems to have accommodated the acrolectal pattem through the introduction of the connective particle into the serial cluster without concomitant OV order.

da siiet en gesels jy nôu. Ja wa ... Sit a gasels omtrent (Van Rensburg, ed., 1984:II.270)

'there you sit and talk now. Yes, sir, sit and talk some'20

The projection of the connective particle into the double infinitive following tensed auxiliaries is, I would suggest, both acrolectal and late. With the Netherlandicization of verb serialization with en as the "hook", Kuryłowicz's second law of analogy (1947) would plausibly describe the mechanism for this extension: "Analogical developments follow the direction 'basic form $\rightarrow$ derived form', where the relationship between basic and derived forms is a consequence of their spheres of usage". ${ }^{21}$ As for the relative chronology, Mansvelt's ldioticon (1884) contains a most revealing lemma for staan, which, he wrote, is used as an auxiliary verb expressing duration, "zelfs daar waar de oorspronkelijke beteekenis in lijnrechte tegenspraak is met den zin (Mansvelt 1884 [1971:204]):

(47) a. Hij het di heele morre staan rondloop.

'He just ran around [doing nothing] all morning'.

b. Hoe kan ik dan hier bij jou staan sit

(terwijl ik b.v. druk werk heb)?

'How can I just sit around here with you

(while I have, for example, pressing work to do)?'

c. $\quad \frac{\text { staan-sit-sit, herhaaldelijk gaan zitten }}{\text { 'sit down repeatedly' }}$

Clearly, Mansvelt's interest in this item obtains from the fact that staan can express durative aspect regardless of the lexical meaning of the main verb. Yet, I find it somewhat remarkable that there is no explicit mention of the connective particle (or for that matter the optional past participle prefix) given that this feature is all but unknown in the metropole.

Let us tum next to the past participle marking of the positional verb. The source of the ge- before the positional verb lies in the basilect. Consider Louis Trigardt's rendering of the "broken" Cape Dutch of the Alsation bywoner Albach: 
(48) a. ik ook gehelp daar zoo, ou Lowies. ik warrem gemaak de eijser; das waar, ou Lowies. Ik nie keslaan; ou Hendrik keslaan mijn wiel. ... ouwe Henderik keslaan, ou Lowies; ik nie keslaan (25 May 1837)

'I helped over there, too, old Louis. I heated the iron; that's true, old Louis. I didn't beat; old Hendrik beat [i.e., hammered] my wheel. Old Hendrik beat, old Louis, I didn't beat'

b. Ik kaloo! die dag; ik zoo kaloop. Ouw Lowies weet ... Gert voor kaloop ikke nie kakijk. ... Ik zoo door kaloop: (3 August 1837)

'I went that day; I went thus; Old Louis knows ... Gert went before; 1 didn't look ... I went on through'.

What is immediately striking is his frequent omission of perfect auxiliaries. This absence would appear to be nothing more than an artifact of Albach's defective knowledge of Cape Dutch representing one individual's solution to the problem of cross-linguistic communication. I believe, however, that the standard view on Albach's quoted speech ignores pertinent facts, among them the prospect that $g e$ (together with its variant form $\mathrm{ga}$ ) may also have functioned as an unbound tense marker in creolized Cape Dutch; that is, without the Dutch perfect auxiliaries hebben and zijn, though its syntax would not have been commensurable with that of the positional verbs. ${ }^{22}$ Albach, let us not forget, was a member of the lowest class of Whites and was married to a woman of color; their children are described by Trigardt and his son Carolus as "bastards". In terms of personal character Trigardt's portrayal of Albach is most unflattering; one gains the impression of an abusive, cruel, and ignorant individual. While one should be chary of uncritically equating quoted speech with actual speech, one cannot ignore the fact that Trigardt had every incentive to place basilectal forms in Albach's mouth. Many of the forms attributed to Albach are found in Orange River Afrikaans, and this cannot be a matter of coincidence.

Direct evidence for the omissibility of het/had in Orange River Afrikaans is at best tenuous. One bears the burden of demonstrating by a preponderance of evidence that such omissions, which are not infrequent in contemporary sources, are not merely pragmatic, such as the ellipsis that we find in (49):

Informant: Baas, ons het jare gebly, jare gebly.

Interviewer: Daar onder?

Informant: Hier in die Griekeland [sic]. Jare gebly. (Van Rensburg, ed., 1984:11.288-89)

'Master, we stayed for years; stayed for years.

Down there?

Here in Griqualand. Stayed for years'.

I have so far found only one totally unambiguous case of auxiliary suspension, where an event anterior to the time in focus is introduced for the first time in a discourse: 
$(50)$

Interviewer: En bring een van u kinders $u$ hier na die werk toe?

Informant: Ja die een seen bring my op werk toe hiermatoe en hy kom hool my hier. Dis die ene wat 'n onderwyser is. Da kom haal hy my hier, saans ok, sos meneer gesien gistraand (Van Rensburg, ed., 1984:11.212).

'And does one of your children bring you here to work? Yes, the one son brings me to work here, and he comes and gets me here. This is the one who is a teacher. He comes and gets me here, evenings, too, like you saw yesterday'.

There is, however, considerable more robust indirect evidence for $\mathrm{ga}$-/ge- having been a tense marker in Cape Dutch creole.

First, there is the use of this particle even with verbs containing unstressed (inseparable) prefixes, most prominently be-, er-, her-, ont-, ver-. These verbs do not take the past participle marker in either standard Afrikaans or Dutch. ${ }^{23}$ Extensions of ge-/ga in Orange River Afrikaans (e.g., (51a)) would appear to be mere hypercorrections conditioned by imperfect knowledge of the superstrate (Jenkinson 1984:248-49). Notwithstanding the initial plausibility of such a view from a strictly synchronic perspective, $(51 \mathrm{~b}-c)$ make it all but certain that this phenomenon is both vestigial and strictly basilectal.

a. Orange River Afrikaans:

hille't eers drie sielings gepesagl (Van Rensburg, ed., 1984:Il.180)

'they first paid three shillings'

b. Boniface, "Hendrik Kok" (1830):

Hy het voor my eerlyk gebetoal. (Nienaber, ed., 1971:39).

'He paid me fairly'.

c. Trigardt diary (Albach):

Ik twee schaap al kebetaal (25 May 1837)

'I already paid for two sheep'

There is not a trace of this particular hypercorrection in the Cape Dutch letters of French Huguenots from the early eighteenth century (Pheiffer 1980:105). Dialectal Early Modem Dutch cannot be a factor here, as the Cape Dutch source material marshalled by L.C. van Oordt attests but six tokens of a single verb in which the past participle prefix has been affixed to an inseparable prefix (gemishandeld); cf. Scholtz 1972:21-22. The only text from the Dutch colonial period in which this phenomenon is otherwise represented is in the report of Hendrik Wikar (1779), a Swede who deserted the Dutch East India Company and joumeyed among the Khoikhoi along the Orange River. ${ }^{24}$

Second, Orange River Afrikaans shows reflexes of both present (het, ' $t$ heeft) and preterital (had, ha) forms of the Dutch tense auxiliary verb hebben, even though no variety of Afrikaans has retained an opposition between perfect and plu-perfect. 
Die goue pondjiie bas? Ja, ek had hulle gakien bas. Ek het die tiensielings ok gakjen. (Van Rensburg 1984:II.275)

'The gold pound coin? Yes, I knew it. I knew the ten shilling piece, too'

The "Hottenot" scenes in Boniface's farce De nieuwe Ridderorde of de Temperantisten (1832) contain hat (had) exclusively, which is indicative of a stereotype. Louis Trigardt's direct quotation of Albach's speech vacillates between had, het, and zero --. frequently with prefix showing a lowered vowel (ga-), an allomorph of ge- that is very common in Orange River Afrikaans.

a. Boniface, Temperantisten (1832):

Ik hat anders niks gezeg as dat jy dronk was.

'I didn't say anything except that you were drunk'.

b. Trigardt diary (Albach):

Z(ei) Albagh: Wanneer ikke kepraat? Nooijt ik had kepraat. Ik had kevank de Boesman; nooijt ik had kabring; ik kad lsicl doot kemaak (8 September 1837).

'Albach said: When did I say that? I never said that. I caught the Bushman; I never brought [him] along; I killed'.

c. Trigardt diary (Albach):

Gester ik het kemaak voor owe Hendeerik een tank (25 May 1837) 'yesterday I made a pair of tongs for old Hendrik'

I attribute this vacillation to the process of decreolization, during which tense auxiliaries were reintroduced. But as the Cape Dutch creole moved closer to the superstrate, not all inflectional categories. were restored, even when their former exponents managed to survive. The result is a residue of allomorphy that serves no linguistic function. Note further that the finite forms het 'has, have' and was 'was, were' can also become past participles in Orange River Afrikaans: ORA het gewas (= ga + the preterite was 'was'), het gewees, het gehet beside Standard Afrikaans was (colloquial was gewees), "het gewees, het gehad. These suppletive preterites, too, must have received the presumed tense particle $g e / g a$ in the Cape Dutch creole.

Third, when the past participle prefix ge-/ga-occurs in the perfect with semiauxiliaries (such as loop, kom, laat) in Orange River Afrikaans, it's placement is highly variable. ${ }^{25}$ The prefix can precede either the semiauxiliary verb or the main verb; alternatively, it can precede the semiauxiliary and be copied onto the main verb.

(54) a. en in die dorp gelôop bly het (Van Rensburg, ed., 1984:II.171) 'and went and stayed in the village' 
a'. Cf. Ons Klyntji, II, ca. 1896 , p. $89 f$.

[cited from Hesseling 1899:129-30]:

... het deusman se kind ni ge le [sic] staan oplet, hoe boer se kind le stan ferwonder by di plaas, hoe krikwa se kind le stan lees die krant ni?

'Didn't the European ['s child] take notice of how the farmer ['s child] is standing amazed by the farm, how the Griqua ['s child] is reading the newspaper?'26

b. daár had IhyJ loop sekamp (Van Rensburg, ed., 1987:81)

'there he went to fight'

b'. Cf. Witbooi diary (1888 [1929:20]):

ik heb ... op uwe poort kom gestaan

'I have come to stand at your gate'

b". Cf. Witbooi diary (1889 [1929:47 et passim]):

Ten 6 Junij is onze oorlog weer uit gegaan en !Areb loop geschiet en ten $7 \mathrm{Junij}$ die plaats verbrand.

'On the 6th of June our war resumed and !Areb went to shoot [perhaps opened fire] and on the 7th of June burned the farm'.

c. Baie van die mense het geloop gesténwe van hartseer (Van Rensburg, ed., 1984:11.131)

'many of the people up and died of sorrow'

c'. Cf. Trigardt diary (Albach):

noijt nie ikat weer kekom kepraat (27 June 1837)

'I never came to speak again'

Note in particular how in the passive construction in (55) the past participle prefix has attached to the semiauxiliary and not to the main verb.

en hille tonge word gelop drai lat helle nôu Affirkans spreek (Van Rensburg, ed., 1984:II.143)

'and their tongues are turned/twisted now that they speak Afrikaans'

There are also instances when the semiauxiliary precedes the complements and adjuncts of the main verb.

(56) a. Toe't hy nôu galoop trôuring annie vinger set (Van Rensburg, ed., 1984:II.247) 'Once he placed a wedding ring on the finger'

b. daar het die ou in die Boere-oorlog loop vernietig geraak (Van Rensburg, ed., 1984:11.294)

'there the old fellow was destroyed in the Boer War' 
c. Daar was nie kaptein gakies nie. Die Kaapse Gowerment het geloop Captain Blayi hier gestuur. En die't die mense gakom koudbloedig plat geschkiet [sic] (Van Rensburg, ed., 1984:II.37)

'There was never a captain elected. The Cape Government sent Captain Blayi here, and it came and shot the people down in a cold-blooded way'

The instantiation of $g e / g a$ as an unbound tense marker is difficult to expl ain at present. My guess is that it emerged from the simplified registers (foreigner talk) of Europeans, who used OV word order and dispensed with the Dutch auxiliaries hebben and zijn altogether. In Khoikhoi pidgin Dutch this morpheme preceded a lexical verb but was recodified as essentially $\stackrel{\sim}{N}$ a free form, perhaps in line with tense particles in the mother tongue (cf. Nama ra/a, go, ge $\underset{5}{N}(g y e)$, and $n i$ for present, past, perfect, and future respectively; cf. Den Besten 1978:45). I take (54a), (55), and (56a) to represent the prototypical structure for Orange River Afrikaans. $\because$ Accordingly, the ensuing Cape Dutch creole deployed ge/ga as its tense marker, with the tense ${ }_{\infty}^{-}$auxiliaries hebben and zijn not making their reappearance until perhaps the late eighteenth of century under the influence of superstrate Dutch. Although $\mathrm{ge}$-/ga- is joined to the verb in fi standard orthographic practice, the data above suggest that the morpheme was a grammatical

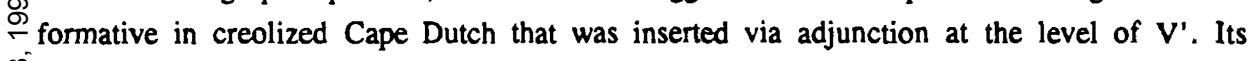
N attraction to the main verb $(54 \mathrm{~b}, 56 \mathrm{~b})$ could be due to its moveability or to the influence from $\overline{\bar{O}}$ the superstrate. The double marking in (54c) and (56c) can be seen as a kind of concord. ${ }^{27}$

if Returning now to the optional past participle marking on the positional verb of the hendiadys, I would claim that it is a basilectal form that percolated into acrolectal Cape Dutch Sand has found recognition in the standard language, albeit optionally and only with the connective particle en:

The motion verb loop had become a hallmark of Cape Dutch by the early nineteenth century, as we have seen in the examples in (25). Concerning the positional verbs, Changuion (1848:xvii) listed only loop in his Proeve, describing it strictly (and somewhat pejoratively) as a motion verb:

Loopen; dit w. voor wandelen te gebruiken, heeft, dunkt mij, iets onbeschaafds. Met het bijw. hard, wordt het als zamengest. wkw. gebruikt, en hoort men: $i k$ hardloop, in plaats van ik loop hard, bij het gehardloop! enz.

Pannevis (ca. 1880 [1971:97]) discerned the tendency for loop to occur where one might expect gaan to indicate movement away from a deictic center (cf. the examples in (24)):

Loop, ww. ook weggaan (b.v. kom, ons moet loop, kom, wy moeten weggaan). Ook wordt het vaak gebruikt waar de Hollander gaan zegt, b.v. loop haal die koerant, ga de krant halen; loop lèh, gaan liggen, enz. Doch men bezigt hier ook gaan. 
His lemmata for $l \hat{e}$, sit, and staan indicate no special properties. Mansvelt (1884 [1971:181]) appears to have been only fleetingly aware of even this deployment of loop:

Loop, als imperatief gebruikt met haal voor: ga halen of haal eens even. Waarsch. 't Fr. allez chercher.

At first blush, the meaning of the hendiadys with loop 'walk along doing something' would appear entirely incompatible with its partially camouflaged meaning in the basilect (punctual, momentary action). Consider the following exchange in the Trigardt diary between Albach and Jan Pretorius, another member of trek.

Kwam ouw Albagh en vraag aan Jan of hij loep kijk. Jan andwoorde: Waar zal ik loop? (Trigardt diary, 8 September 1837)

'Old Albach came and asked Jan whether he is going to look. Jan answered: Where shall I go?'

It may be that Albach's interlocutor has understood the question a bit to literally, but his response illustrates how narrowly preverbal loop could be construed as motion verb.

I believe the interpolation of en between loop and its main verb in a hendiadys represents a basilectal hybridization, the foundation for which was laid by the introduction of hendiadys forms already established in the acrolect (i.e., with staan, $l \hat{e}$, and sit) into the basilect (supra). That the loop-hendiadys was a secondary basilectal creation is confirmed by what appears to be a hypercorrect hendiadys with the verb leer 'teach' (58) that is attested in Orange River Afrikaans:

loep ek my pa't my klar galeer en skeer toe kom ek oor (Van Rensburg, ed., 1984:II.20)

'I went [when] my pa had finished teaching me to shear [sheep] then I came over'

The basic idea linking acrolectal and basilectal deployment of loop in Cape Dutch is that initialization occurs at just one point in time but introduces a process or state.

Trigardt diary (Albach):

Almage, Carol, mijn eenigs os is wek. ... Ikke wel somar stuur Isaak, hij moet loop kiik de hos; owe Henderik ze Diderik moet oppas de jos (20 May 1837)

'God Almighty, Carolus, my only ox is gone. I want to send Isaac, he must go look [start looking] for the ox; old Hendrik says Diederichs is supposed to watch the ox'

Orange River Afrikaans provides evidence for the bridge structure between (59) and the acrolectal hendiadys. 
Dit is nou innie daghe in wat ons nou lôp en, sô loop en soek (Van Rensburg, ed., 1984:II.162)

'It is now in the days [vis-à-vis nights] when we go looking'

In this scenario, the introduction of the connective particle en modified the meaning from one of an initialized, ongoing process to one denoting iterativity. Acrolectal Cape Dutch accepted the innovative loop-hendiadys structure from basilectal Cape Dutch but kept it within the semantic frame of the lexical motion verb loop, whence continuous, simultaneous activity with ọspecific involvement of movement.

5. Summary

ก

Bosman (1923:83) was uncertain whether it is even possible to determine whether the Thendiadys that occurs in standard Afrikaans is a creolism or Netherlandicism; but he did see isome merit to both positions: "In elk geval blyk dat die kreolismes aansluiting het by Hollands en dus gemakliker kon oorgeneem word in beskaafde Afrikaans." If my account is anywhere Onear correct, this speculation was surely prescient.

$\stackrel{\infty}{i} \quad$ Reexamination of the philological record indicates that the Afrikaans hendiadys cannot örepresent the generalization of a pattern existing in vernacular Early Modem Netherlandic. Nor wdoes Orange River Afrikaans show a clear prototypical form of the hendiadys construction. Rather, this etymology involves a long process of mutual adaptation, accommodation, and Gonvergence between substrate and superstrate. Preverbal aspectual markers in the basilect Junderwent Netherlandicization in superstrate Cape Dutch to merge with hendiadyslike $\frac{5}{\omega}$ constructions exported from the metropole. Integration was facilitated by the introduction of סthe conjunction en in accordance with the V2/OV typology, although concessions were made to Jthe basilectal equivalent (which we do find in colloquial Afrikaans). It was also acrolectal Cape oDutch that extended the connective particle into double infinitive constructions following tensed $\frac{\bar{\Phi}}{\bar{\Phi}}$ auxiliary verbs. Basilectal Afrikaans donated the past participle inflection of the positional verb Win the past tense and innovated the loop-hendiadys, even while making concessions to acrolectal forms.

This sequence of events seems to lie at the heart of what I understand a semicreole to be. Measured against "true" creoles, semicreoles clearly lack the massive restructuring of the grammatical systems. What we find instead is a cycle of incremental innovation, accommodation, and integration where there exists the requisite goodness of fit. The end result is often hybrids that are etymologically opaque to the extent that they are not directly relatable to any of their putative antecedents. What is impossible in the analysis of contact-induced linguistic change --- like anything else --- is to reduce a complex state of affairs to a single causal factor. Any such analysis will remain primitive as long as it is conducted within an "either/or" framework. 


\section{NOTES}

1. Synchronic descriptions of the hendiadys construction are in Heiberg 1963:140-44; Kempen 1965:77-81; Ponelis 1979:241-42; Raidt 1983:179-80; Donaldson 1993:220$21,226,385-87$.

2. Heiberg 1963:142-43, Ponelis 1979:241-42, Van Rensburg 1989:146, Links 1989:7677, Donaldson 1993:220n.

3. Cf. Kempen 1965:91, Donaldson 1993:386-87.

4. Cf. also Le Roux 1947:52, Heiberg 1963:141n., De Villiers 1983:147.

5. Le Roux 1923:152-53, 1947:52; Bouman 1926:24-26, 46; Heiberg 1963:144-47; Kempen 1965; Smuts 1969:39; Raidt 1983:180-81, 1991:228-29; Links 1989:78.

6. Bouman 1926:25, Kempen 1965:85-86, Raidt 1983:180-81.

7. Cf. Bouman 1926:46: "Er kunnen namelik twee wendingen parallel gebruikt worden: 1. hy staan en kyk en 2. hy staan kyk, waaruit valt af te leiden dat ook in tiepe 1 met het bindwoord en de tweede w.w.-vorm een infinitief is, en geen verbum finitum meer. Waarschijnlik is het prototiepe hiervan te vinden in de zinnen met een hulpw.w., waarbij naast elkaar kwamen: hy sal staan kyken en hy sal staan en kyken, en dan ook: hy staan kyk en hy staan en kyk. Hierbij is in 't oog te houden dat de twee w.w. een semantiese eenheid uitmaken. Het spreekt vanzelf dat na de deflexie, na het samenvallen dus van alle w.w.-vormen, de tweede vorm nog als verbum finitum kon worden opgevat, en ook is opgevat. Opm. -.. Het omgekeerde, dat namelik deze wijziging in opvatting mede-oorzaak zou kunnen zijn van de deflexie, lijkt mij niet uitgesloten."

8. Kempen 1965:86-87, 94; Raidt 1983:181.

9. On the bleaching of Dutch liggen see Stoett 1923: par. 14, WNT VIII/2, col. 2166, Kempen 1965:89.

10. I give twelve of Raidt's thirteen examples in (21-24). In all but one case I have restored ellipses and provided references to the archival materials collected by L.C. van Oordt which, though unpublished, exist in numerous bootleg copies. I have also made one minor correction. The thitteenth sentence (42) will be discussed in the following section.

11. Cited from Raidt 1983:181. My own copies of the archival materials appear to be missing this particular document.

12. Heiberg 1963:142-43, Kempen 1965:79, Ponelis 1979:241, Raidt 1983:18.

13. Rademeyer 1938:78, Makhudu 1984:88-89, Stolz 1986:180, Holm 1988:157.

14. Rademeyer (1938:78) wrote: "Op my vraag aan 'n ou Griekwa hoe die woordjie le nou eintlik gebruik word, was sy antwoord dat dit gebesig word $\mathrm{min}$ of meer in die sin van 
$l \hat{l}-l \hat{e}$, d.w.s. stadigies, staan-staan, praat-praat." Mansvelt included a lemma for this reduplicated variant of $1 \hat{e}$ (1884 [1971:179]), which, according to him, expresses ongoing action that is intermittently interrupted.

LA-lề (lê = leggen), liggende; b.v. hij eet lê-lé. Ook dient 't om een telkens afgebroken handeling uit te drukken, b.v. $l e-l e \hat{e}$ sit, -.--- loop, enz.

15. Cf. Schutter and Van Hauwermeiem 1983:170-71, Kirsner 1993.

फ़16. Less certain is as die hart loop dood (idem, p. 82) 'when the heart is dead, i.e., has stopped beating' (as ' $n$ mens se hart gaan staan), literally 'goes dead' in view of Dutch doodlopen 'come to a dead end' (as in doodlopende weg, straat 'dead-end street', Afrikaans 'n straat wat doodloop 'a street with no outlet').

17. Du Toit 1905:94-95, Valkhoff 1972:23, Makhudu 1984:89, Stolz 1986:180, Holm 高 1988:157, Van Rensburg 1989:146-47, Den Besten 1988:32-40.

Similarly Den Besten (1978:44-47), since revised.

19. This caveat also applies mutatis mutandis to the Netherlandicist position. Recall that Kempen (1965:89-90) concluded that in certain respects the Orange River forms are "ouer en Nederlandser" than those of standard Afrikaans.

But in the interrogative, according to Donaldson (1993:220) "one has a choice of word order: Wat lê en dink jy/Wat lê jy en dink? 'What are you lying there thinking about?' Where the subject is stressed, only the second option is possible."

Translation cited from Hock 1986:212. Hock goes on to explicate the "sphere of usage provision" as follows: "Of any given set of forms or morphological there syntactic -.. PTR] classes, the one which has a greater sphere of usage is more 'basic' than the others" (p. 214).

22. The ke-/ka- in Albach's quoted speech are to be seen as the substitution of (unmarked) voiceless velar stops for (marked) velar fricatives.

क्षे 23. Donaldson (1993:224n.) does note that "in very colloquial Afrikaans the perfective prefix ge- is sometimes added to verbs with inseparable prefixes, e.g., geontmoet, gebegrawe."

24. Here we find nine occurrences of the extension, of which only two are active (gebeschaart, p. 90, gevereerd, p. 192) and seven are passive (gebewaar, p. 58, gebeloofi, p. 72, gebepist, p. 92, gebewaard, p. 96, gebegraven, pp. 112, 194, gevernielt p. 122).

25. Recall that in Standard Afrikaans we should expect a double infinitive in the perfect with semiauxiliaries, although in very colloquial speech they commonly take the past participle form cf. Donaldson 1993:225-26, 274-75.

26. Rademeyer (1938:78) found this sentence more than a little contrived: "Alles is hier sterk oordrewe, nie net wat betref die veelvuldige gebruik van lê nie, maar ook die 
herhaling van se kind agter Griekwa en deusman. Dis heeltemaal duidelik dat hierdie teks samgeflans is in die studeerkamer, en nie opgeteken is uit die mond van die sprekende indiwidu nie." For us, it is the usage of the past participle marker ge- that is of interest, with which Rademeyer apparently had no quarrel.

27. In the archival source material we find heeft gecogt gehod 'had bought' (CJ 1030, p. 356,1717 ), heeft gegeven gehad 'had given' (CJ 378, p. 268, 1762), and is staan gebleeven 'stood standing' (CJ 391 , p. 255, 1767). 


\section{REFERENCES}

Besten, Hans den. 1978. Cases of possible syntactic interference in the development of Afrikaans. In Pieter Muysken, ed., Amsterdam creole studies II, 5-56. (Publikaties van het Instituut voor Algemene Taalwetenschap, 20.) Amsterdam: University of Amsterdam.

---. 1988. Universal-Grammatik und/oder Zweitsprachenerwerb: Der Fall Afrikaans. In Norbert Boretzky, Wemer Enninger, and Thomas Stolz, eds., Beitrage zum 4. Essener Kolloquium über "Sprachkontakt, Sprachwandel, Sprachwechsel, Sprachtod" vom 9.10.-10.10 1987, 11-44. Bochum: Studienverlag Dr. N. Brockmeyer.

Bosman, D.B. 1923. Oor die ontstaan van Afrikaans. Amsterdam: Swets \& Zeitlinger.

Bosman, F.C.L., ed. 1954. C.E. Boniface, De nieuwe ridderorde of de temperantisten [1832]. (Patriot-Vereniging, 12.) Johannesburg: Voortrekkerpers.

Bouman, A.C. 1926. Onderzoekingen over Afrikaanse sintaxis. (Annale van die Universiteit van Stellenbosch, jaargang IV, reeks B, afl. 3.) Cape Town: Nasionale Pers.

Brachin, Pierre. 1985. The Dutch language: A survey. Trans. by Paul Vincent. Leiden: E.J. Brill.

Changuion, A.N.E. 1848. De nederduitsche taal in Zuid-Afrika hersteld. Proeve van Kaapsch taaleigen (Bijvoegsel). 2de druk. Rotterdam: J. van der Vliet.

de Klerk, W.J. 1968. Dialektiese verskeidenheid in Afrikaans. In H.J.J.M. van der Merwe, ed., Afrikaans: sy aard en ontwikkeling, 219-39. Pretoria: J.L. van Schaik.

de Villiers, Meyer. 1983. Afrikaanse grammatika vir volwassenes. Cape Town: Nasou.

Donaldson, Bruce C. 1984. Dutch reference grammar. Leiden: Martinus Nijhoff.

-.-. 1993. A grammar of Afrikaans. (Mouton grammar library, 8.) Berlin and Nelv York: Mouton de Gruyter.

du Plessis, H.G.W. 1984. Sintaksis. In Van Rensburg, ed., 1984, I.35-195. 
du Toit, P.J. 1905. Afrikaansche studies. (Doctoral dissertation, Ghent.) Ghent: A Siffer.

Franken, J.L.M., ed. 1938. Duminy-Dagboeke. (Van Riebeeck Society, 19). Cape Town: Van Riebeeck Society.

Heiberg, L.R. 1963. Twee Afrikaanse volkstaalkonstruksies. In T.J.R. Botha, ed., Taal en teken: Bundel opgedra aan Prof. G.S. Nienaber, 140-148. Cape Town and Pretoria: Academica.

Hesseling, D.C. 1899. Het Afrikaansch. Leiden: E.J. Brill.

---. 1905. Het Negerhollands der Deense Antillen. Leiden: A.W. Sijthoff.

---. 1923. Het Afrikaans. 2nd ed. Leiden: E.J. Brill.

Hock, Hans Heinrich. 1986. Principles of historical linguistics. (Trends in linguistics, Studies and monographs, 34.) Berlin, New York, and Amsterdam: Mouton de Gruyter.

Holm, John A. 1988. Pidgins and creoles. Vol. 1: Theory and structure. Cambridge: Cambridge University Press.

Jenkinson, A.G. 1984. Morfologie. In Van Rensburg, ed., 1984, I.229-53.

Kempen, W. 1965. Die verbale hendiadis in Afrikaans. In E. Lindenberg, Edith H. Raidt, and J.A. Verhage, eds., Dietse studies: Bundel aangebied aan prof. dr. J. du Plessis Scholtz, 77-97. Cape Town and Pretoria: Academica.

Kirsner, Robert S. 1993. On explaining what is not: The missing Dutch 'future perfect' with gaan. Paper presented to the Fourth Annual Michigan-Berkeley Germanic Linguistics Roundtable, University of Michigan, Ann Arbor, April 15-17, 1993.

Kuryłowicz, Jerzy. 1947. La nature des procès dits analogiques. Acta linguistica 5.17-34.

le Roux, J.J. 1923. Oor die Afrikaanse sintaksis. (Doctoral dissertation, Utrecht.) Amsterdam: Swets \& Zeitlinger. 
-.-.. 1947. Die bou van die Afrikaanse taal. In C.M. van den Heever and P.. de Villiers Pienaar, eds., Kultuurgeskiedenis van die Afrikaner, 2:40-72. Cape Town, Bloemfontein, and Port Elizabeth: Nasionale Pers.

le Roux, T.H., ed. 1964. Die dagboek van Louis Trigardt. Pretoria: J.L. van Schaik.

Links, Tony. 1989. So praat ons Namakwalanders. Cape Town: Tafelberg.

@̊̀ Makhudu, Dennis P. 1984. Is Afrikaans a creole language? MA Thesis, Southern milinois $\stackrel{\infty}{\mathcal{J}}$ University. Ann Arbor: University Microfilms Intemational.

กิ

Mansvelt, N. 1884. Proeve van een Kaapsch-Hollandsch idioticon. Utrecht: A.J. van Huffel. 言 Rpt. Van der Merwe, ed., 1971:129-221.

\$Mossop, E.E., ed. 1935. The joumal of Hendrik Wikar (1779). (Van Riebeeck Society, 15.) Ð $\quad$ Cape Town: Van Riebeeck Society.

$\stackrel{\aleph}{N}^{\circ}$ jenaber, G.S., ed. 1971. Afrikaans in die vroeèr jare. (Patriot-Vereniging, n.s., 4.). $>$ Johannesburg: Voortrekkerpers.

尹annevis, Arnoldus. ca. 1880. Unpublished list of Afrikaans words and expressions. Rpt. Van $\stackrel{\leftrightarrows}{\leftrightarrows} \quad$ der Merwe, ed., 1971:59-127.

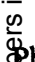
\$heiffer, Roy H. 1980: Die gebrake Nederlands van Franssprekendes aan die Kaap in die eerste helfie van die agtiende eeu. Cape Town, Pretoria, and Johannesburg: Academica.

定 悉

Rademeyer, J.H. 1938. Kleurling-Afrikaans: Die taal van die Griekwas en Rehoboth-Basters. Amsterdam: Swets \& Zeitlinger.

Raidt, Edith H. 1983. Einfihhrung in Geschichte und Struktur des Afrikaans. Darmstadt: Wissenschaftliche Buchgesellschaft.

---. 1991. Afrikaans en sy Europese verlede. 3rd ed. Cape Town: Nasou. 
Roberge, Paul T. 1994. On detecting a prior linguistic continuum in Cape Dutch. In Gerrit Olivier and Anna Coetzee, eds., Nuwe perspektiewe op die geskiedenis van Afrikaans, 153-65. Johannesburg: Southern Books.

Scholtz, J. du Plessis. 1972. Afrikaans-Hollands in die agtiende eeu. Cape Town: Nasou.

Schutter, G. de and P. van Hauwermeiern. 1983. De structuur van het Nederlands: Taalbeschouwelijke grammatica. Malle: De Sikkel.

Smuts, J. 1969. Vroeë Afrikaans. (Afrikaanse taalmonografiee, 4.) Cape Town: Nasou.

Spears, Arthur K. 1982. The Black English semi-auxiliary come. Language 58.850-72.

Stoett, F.A. 1923. Middelnederlandsche spraakkunst. 3rd ed. The Hague: Martinus Nijhoff.

Stolz, Thomas. 1986. Gibt es das kreolische Sprachwandelmodell? Vergleichende Grammatik des Negerhollandischen. Frankfurt a.M., Bern, and New York: Peter Lang.

Valkhoff, Marius F. 1972. New light on Afrikaans and "Malayo-Portuguese". Louvain: Éditions Peeters Imprimerie Orientaliste.

van der Merwe, H.J.J.M. ed. 1971. Vroee Afrikaanse woordelyste. (Patriot-Vereniging, n.s., 5.) Pretoria: J.L. van Schaik.

van Oordt, L.C., ed. 1947-56. Die Kaapse taalargief. Parts 1-4 privately published, Cape Town; parts 5-10 in Tydskrif vir wetenskappe en kuns 10.65-88, 11.55-75, 12.73-101, 13.45-73, 14.33-56, 16.97-124.

van Rensburg, M.C.J. (project director). 1984. Die Afrikaans van die Griekwas van die tagtigerjare. Bloemfontein: University of the Orange Free State.

van Rensburg, M.C.J. (project director). 1987. Finale verslag van die groter navorsingsprojek: Gesproke Afrikaans: Die Afrikaans van die Richtersveld. Bloemfontein: University of the Orange Free State. 
van Rensburg, M.C.J. 1989. Orange River Afrikaans: A stage in the pidgin/creole cycle. In Martin Pütz and René Dirven, eds., Wheels within wheels: Papers of the Duisburg Symposium on Pidgin and Creole Languages, 135-51. (Duisburger Arbeiten zur Sprachund Kulturwissenschaft, 5.) Frankfurt a.M., Bern, New York, and Paris: Peter Lang.

Weijnen, A. 1968. Zeventiende-eeuwse taal. 5de druk. Zutphen: W.J. Thieme.

仓o Witbooi, Hendrik. 1929. Die dagboek van Hendrik Witbooi, Kaptein van die WitbooiHottentotte 1884-1905. Edited by the Suidwes-Afrika Wetenskaplike Vereniging, Windhoek. (Van Riebeeck Society, 9.) Cape Town: Van Riebeeck Society. 